\title{
Molar Pregnancy and Poor Obstetrics Outcome: Retrospective Evaluation of Six Cases
}

\author{
Mert Turgal $^{\mathrm{a}, \mathrm{b}}$, Mehmet Sinan Beksac ${ }^{\mathrm{a}}$
}

\begin{abstract}
In this case series, we aimed to determine obstetrical history features of our patients who had experienced hydatidiform mole in their previous pregnancies. There were two patients who had heterozygous mutation for methylene tetrahydrofolate reductase (MTHFR) enzyme. One patient had both factor V Leiden and methylene tetrahydrofolate reductase enzyme heterozygous mutation. Excluding hydatidiform mole pregnancies, these six patients had 17 pregnancies totally. Eleven pregnancies $(64.7 \%)$ experienced obstetrical/perinatal complications during their pregnancies. The most common complications were miscarriage, anomalous fetus, and mental retarded child. In conclusion, we advise obstetricians to be careful when their patients experienced hydatidiform mole in their previous pregnancies.
\end{abstract}

Keywords: Hydatidiform mole; Hereditary thrombophilia; Pregnancy complications

\section{Introduction}

Gestational trophoblastic disease (GTD) is a group of pathologies that originate from the abnormal hyperproliferation of trophoblastic cells. GTD includes different conditions such as hydatidiform mole (HM) (complete or partial), invasive mole, gestational choriocarcinoma, placental-site trophoblastic tumor, and epithelioid trophoblastic tumor. The most common GTD is HM. HM is a gestational disease with abnormal development of the villous trophoblast and characterized by an excess of paternal to maternal genetic material. It occurs once in every 600 pregnancies in Western countries but at higher rates in the Middle East, Latin America, Africa, and the Far East [13]. The most important risk factors for the development of HM

Manuscript accepted for publication April 28, 2016

aDepartment of Obstetrics and Gynecology, Hacettepe University School of Medicine, Ankara, Turkey

${ }^{b}$ Corresponding Author: Mert Turgal, Department of Obstetrics and Gynecology, Hacettepe University School of Medicine, 06100, Sihhiye, Ankara, Turkey. Email: mertturgal@gmail.com

doi: http://dx.doi.org/10.14740/jmc2495w are maternal age, geographical factors including ethnicity, and a previous molar pregnancy [4].

Women with GTD history appear not to be at increased risk of adverse pregnancy outcomes, although there have been some reports of an increased risk of spontaneous abortion, recurrent $\mathrm{HM}$, stillbirth $[5,6]$. In this retrospective evaluation, we have aimed to report the obstetrical history features of our patients who have experienced HM in their previous pregnancies.

\section{Case Report}

This retrospective study was conducted at the Division of Perinatal Medicine, Hacettepe University Faculty of Medicine from January 2010 to December 2012.

The demographic and clinical characteristics of the patients were achieved through patient files and electronic records of the hospital. Patient demographics (age, parity, gravida, etc.), obstetrics history, perinatal complications (miscarriage, chromosomal abnormalities, malformations, and stillbirth) were recorded.

A total of six patients with history for HM were admitted to our hospital from January 2010 to December 2012. The mean age of the pregnant patients was $31.33 \pm 5.33$ years (range: $24-39$ years). The mean gravida of the patients was $3.83 \pm$ 0.75 (range 3 - 5). Details are given in Table 1 . There were two patients who had heterozygous mutation for methylene tetrahydrofolate reductase (MTHFR) enzyme. One patient had both factor $\mathrm{V}$ Leiden and methylene tetrahydrofolate reductase enzyme heterozygous mutation. Excluding HM pregnancies, these six patients had 17 pregnancies totally. Eleven pregnancies $(64.7 \%)$ experienced obstetrical/perinatal complications during their pregnancies. The most common complication was

Table 1. Demographic Features of the Patients

\begin{tabular}{ll}
\hline & Mean \pm SD \\
\hline Maternal age (years) & $31.33 \pm 5.33$ \\
Gravida & $3.83 \pm 0.75$ \\
Parity & $0.83 \pm 0.75$ \\
Miscarriage & $0.50 \pm 0.83$ \\
Alive & $0.67 \pm 0.50$ \\
\hline
\end{tabular}

SD: standard deviation. 
Table 2. Evaluation of the Patients in Terms of Obstetric Outcome and Hereditary Thrombophilia

\begin{tabular}{llll}
\hline Case Number & Obstetric history & Thrombophilic status & Obstetric complication \\
\hline 1 & Miscarriage $\times 2$, partial HM & Normal & Gestational diabetes, placenta previa \\
2 & $\begin{array}{l}\text { Ectopic pregnancy, history for } \\
\text { child with MMR, complete HM }\end{array}$ & N/A & - \\
\hline 3 & $\begin{array}{l}\text { Termination of pregnancy due to } \\
\text { hydrocephalus, complete HM }\end{array}$ & $\begin{array}{l}\text { Factor V Leiden heterozygous, } \\
\text { MTHFR 677 heterozygous }\end{array}$ & History for preterm birth \\
\hline 4 & Complete HM, stillbirth & Normal & Still birth \\
5 & Miscarriage, complete HM & MTHFR 677 heterozygous & Preterm birth, ITP \\
\hline
\end{tabular}

HM: hydatidiform mole; MMR: motor and mental retardation; N/A: non assessment; MTHFR: methylene tetrahydrofolate reductase; ITP: idiopathic thrombocytopenic purpura.

miscarriage (five pregnancies in four patients). Other complications were anomalous fetus, motor and mental retarded child, ectopic pregnancy, preterm birth and stillbirth. Table 2 shows the evaluation of the patients in terms of obstetric outcome and hereditary thrombophilia.

\section{Discussion}

Association of HM and poor pregnancy outcome still remains confusing. Many studies did not reveal adverse perinatal or maternal complications [7]. Results from earlier studies indicate that women with a history of HM can expect a normal subsequent reproductive outcome, except for a slightly increased risk of a recurrent $\mathrm{HM}[7,8]$.

On the contrary, the results of a large national cohort study from Sweden could not demonstrate an association between a history of HM and adverse maternal outcomes in subsequent pregnancies [9]. They have demonstrated an evidence of an increased risk of large for gestational age birth, stillbirth, and preterm birth among women with a history of HM (OR (95\% CI): 1.19, 1.13, and 1.13, respectively). They have also reported that women exposed to a previous HM had a $25 \%$ lower risk of gestational hypertensive disease and preeclampsia when compared to controls [9]. Our findings are consistent with recent literature because there were 11 pregnancies with obstetrical/perinatal complications (64.7\%).

Previous studies revealed that overall recurrence risk for HM was $1.8 \%$ (1 in 55), or a 20 -fold increase compared with baseline risk [6-10]. We did not observe recurrence of HM in our small series probably because of inadequate number of patients.

There have been a lot of published reports about the relationship between MTHFR polymorphism and genetic disorders such as Down's syndrome, cleft lip and palate, congenital heart disease, and neural tube defect [11-13]. In our study, we have shown that $60 \%(3 / 5)$ of the patients had heterozygous mutation for MTHFR enzyme (impaired enzyme activity). When recent literature is reviewed, there were no paper about association between MTHFR enzyme mutation and HM. This DNA methylation disorder may be the triggering reason of empty oocyte which may be the reason of HM. We believe that further studies are needed to validate this finding.

In conclusion, we advise obstetricians to be careful when their patients experienced HM in their previous pregnancies.

\section{Conflicts of Interest}

The authors declare that there is no conflict of interest regarding the publication of this paper.

\section{References}

1. Savage P, Williams J, Wong SL, Short D, Casalboni S, Catalano K, Seckl M. The demographics of molar pregnancies in England and Wales from 2000-2009. J Reprod Med. 2010;55(7-8):341-345.

2. Bracken MB, Brinton LA, Hayashi K. Epidemiology of hydatidiform mole and choriocarcinoma. Epidemiol Rev. 1984;6:52-75.

3. Bracken MB. Incidence and aetiology of hydatidiform mole: an epidemiological review. Br J Obstet Gynaecol. 1987;94(12):1123-1135.

4. Seckl MJ, Fisher RA, Salerno G, Rees H, Paradinas FJ, Foskett M, Newlands ES. Choriocarcinoma and partial hydatidiform moles. Lancet. 2000;356(9223):36-39.

5. Berkowitz RS, Im SS, Bernstein MR, Goldstein DP. Gestational trophoblastic disease. Subsequent pregnancy outcome, including repeat molar pregnancy. J Reprod Med. 1998;43(1):81-86.

6. Garrett LA, Garner EI, Feltmate CM, Goldstein DP, Berkowitz RS. Subsequent pregnancy outcomes in patients with molar pregnancy and persistent gestational trophoblastic neoplasia. J Reprod Med. 2008;53(7):481486.

7. Kim JH, Park DC, Bae SN, Namkoong SE, Kim SJ. Subsequent reproductive experience after treatment for gestational trophoblastic disease. Gynecol Oncol. 1998;71(1):108-112.

8. Matsui H, Iitsuka Y, Suzuka K, Seki K, Sekiya S. Subsequent pregnancy outcome in patients with spontaneous resolution of $\mathrm{HCG}$ after evacuation of hydatidiform mole: 
comparison between complete and partial mole. Hum Reprod. 2001;16(6):1274-1277.

9. Joneborg U, Eloranta S, Johansson AL, Marions L, Weibull CE, Lambe M. Hydatidiform mole and subsequent pregnancy outcome: a population-based cohort study. Am J Obstet Gynecol. 2014;211(6):681 e681-687.

10. Sebire NJ, Fisher RA, Foskett M, Rees H, Seckl MJ, Newlands ES. Risk of recurrent hydatidiform mole and subsequent pregnancy outcome following complete or partial hydatidiform molar pregnancy. BJOG. 2003;110(1):22-26.

11. da Silva LR, Vergani N, Galdieri Lde C, Ribeiro Porto MP, Longhitano SB, Brunoni D, D'Almeida V, et al. Re- lationship between polymorphisms in genes involved in homocysteine metabolism and maternal risk for Down syndrome in Brazil. Am J Med Genet A. 2005;135(3):263267.

12. van Beynum IM, den Heijer M, Blom HJ, Kapusta L. The MTHFR $677 \mathrm{C}->$ T polymorphism and the risk of congenital heart defects: a literature review and meta-analysis. QJM. 2007;100(12):743-753.

13. Amorim MR, Lima MA, Castilla EE, Orioli IM. NonLatin European descent could be a requirement for association of NTDs and MTHFR variant $677 \mathrm{C}>\mathrm{T}$ : a metaanalysis. Am J Med Genet A. 2007;143A(15):1726-1732. 